\title{
GILES OF LESSINES ON STARLIGHT AND THE COLOUR OF THE SKY
}

\section{Introduction}

Giles (Aegidius) of Lessines, a Dominican scholar of the second half of the thirteenth century best known for his writings on usury and the unicity of the substantial form, ${ }^{1}$ composed at least three substantial texts relevant to the history of astronomy: (1) the Summa de temporibus (c.1260/64), which consists of three books on historical chronology and its astronomical underpinnings, ${ }^{2}$ (2) a treatise De essentia, motu et significatione cometarum written in the wake of a comet seen in $1264 ;^{3}(3)$ an undated treatise De crepusculis.

Of these three texts, the one that has by far received the least amount of attention is the third one, which recapitulates and critically examines the calculation of the height of the atmosphere in a work by the eleventh-century Andalusian mathematician/astronomer Ibn Mu'ādh. Giles's De crepusculis is known only from a single manuscript, Bologna, Biblioteca

\footnotetext{
${ }^{1}$ Frederick J. Roensch, Early Thomistic School (Dubuque, IA: Priory Press, 1964), 89-92; Olga Weijers, Le travail intellectuel à la Faculté des arts de Paris: textes et maîtres (ca. 1200-1500), vol. 2, Répertoire des noms commençant par $C-F$ (Turnhout: Brepols, 1996), 62-64.

${ }^{2}$ Only the third book is available in a modern edition: Opera hactenus inedita Rogeri Baconi, vol. 6, Compotus Fratris Rogeri, ed. Robert Steele (Oxford: Clarendon Press, 1926), 1-211. For further details, see C. Philipp E. Nothaft, “'With utmost certainty’: Two Late Medieval Pioneers of Technical Chronology,” Journal of Medieval History 46 (2020): 335-349, at pp. 336-341.

${ }^{3}$ Edited and discussed in Lynn Thorndike, Latin Treatises on Comets between 1238 and 1368 A.D. (Chicago: University of Chicago Press, 1950), 87-184. See also Lys Ann Shore, “The Continuum of Translation as Seen in Three Middle French Treatises on Comets," in Translation and the Transmission of Culture between 1300 and 1600, ed. Jeanette Beer and Kenneth Lloyd-Jones, Studies in Medieval Culture 35 (Kalamazoo, MI: Western Michigan University, 1995), 1-53, at pp. 8-15 (concerning a Middle French translation of the text); John D. North, “Comets, Necessity, and Nature," in The Book of Nature in Early Modern and Modern History, ed. Klaas van Berkel and Arjo Vanderjagt (Leuven: Peeters, 2006), 275-298, at pp. 287-296.
} 
Universitaria, 1845, fols. 89ra-100vb (s. XIV; cited as $B$ in what follows), where the text is preceded by all three books of the Summa de temporibus. ${ }^{4}$ This copy shows heavy signs of textual corruption and was corrected in an unusually large number of places. Empty spaces and drawn circles indicate the intended locations of 16 geometrical diagrams, which must have been present in the archetype but were not carried out by the scribe(s) responsible.

The amount of discussion De crepusculis has received in the modern literature is close to negligible. A 1920 article by Pierre Mandonnet entitled "Gilles de Lessines et son 'Tractatus de crepusculis"' concerned not the text itself, but a description of the Bologna manuscript preserved in the General Archives of the Dominican Order in Rome. ${ }^{5}$ So far, the only scholar to have consulted the actual text in this manuscript appears to be Martin Grabmann, who appended the preface of De crepusculis to a biographical article first published in $1924 .{ }^{6}$ Grabmann did not include any discussion of the text's philosophical or scientific content, which remains entirely unexplored. As I hope to show in what follows, De

\footnotetext{
${ }^{4}$ This is the manuscript catalogued as no. 957 in Lodovico Frati, "Indice dei codici latini conservati nella R. Biblioteca Universitaria di Bologna," Studi italiani di filologia classica 16 (1908): 103-432, at p. 401. The text of De crepusculis here begins "Cum multa secundum verbum sapientis supra subiectum hominis ostensa sint nobis..." and ends “...quanto propinquius scientie poterat prediximus Deo adiuvante cui gloria in secula seculorum. Amen.”

${ }^{5}$ Pierre Mandonnet, “Gilles de Lessines et son 'Tractatus de crepusculis'," Revue néoscolastique de philosophie 22 (1920): 190-194.

${ }^{6}$ Martin Grabmann, “Ägidius von Lessines O. P.: Ein wissenschaftliches Charakterbild aus der ältesten Schule des hl. Thomas von Aquin," Divus Thomas: Jahrbuch für Philosophie und spekulative Theologie, $3^{\text {rd }}$ ser., 2 (1924): 35-54, at pp. 53-54. This article was reprinted with additions as "Einzelgestalten aus der mittelalterlichen Dominikaner- und Thomistentheologie: 1. Ägidius von Lessines,” in Mittelalterliches
} Geistesleben: Abhandlungen zur Geschichte der Scholastik und Mystik, 3 vols. (Munich: Hueber, 1926-1956), $2: 512-530$. 
crepusculis is an unusual work and merits some attention from modern scholars, not least because it deals with scientific questions that were rarely treated in depth in Latin texts of this period. This is true of Giles of Lessines's detailed examination of whether the planets and fixed stars borrow all their light from the Sun, in which he comes down in favour of stellar auto-luminosity. Another intriguing element of this text is Giles's explanation of why the sky appears blue, which uses the extramission postulate to argue that this colour is contributed by the observer's eye. In addition to presenting and contextualizing these two aspects of $D e$ crepusculis, the following pages aim to provide a succinct summary of its content and background.

\section{Ibn Mu 'ädh's 'Liber de crepusculis'}

Before more is said about Giles's De crepusculis, it will be worthwhile first to introduce the author and text that inspired it. Abū 'Abd Allāh Muḥammad ibn Mu'ādh al-Jayyānī served as a judge $(q \bar{a} d \underline{l})$ in the Andalusian town of Jaén during the second half of the eleventh century and authored several important works on mathematics and astronomy, some of which only survive in translation. ${ }^{7}$ His treatise on twilight, for instance, is extant not in Arabic, but in a

\footnotetext{
${ }^{7}$ Yvonne Dold-Samplonius and Heinrich Hermelink, "Al-Jayyān̄̄, Abū 'Abd Allāh Muhammad Ibn Mu'ādh," in Dictionary of Scientific Biography, vol. 7 (New York: Charles Scribner's Sons, 1973), 82-83; María Victoria Villuendas, La trigonometriá europea en el siglo XI: estudio de la obra de Ibn Mu 'āḍ; el Kitāb maŷhūlāt (Barcelona: Instituto de Historia de la Ciencia de la Real Academia de Buenas Letras, 1979); John D. North, Horoscopes and History (London: Warburg Institute, 1986), 35-38; Julio Samsó, Las ciencias de los antiguos en al-Andalus (Madrid: MAPFRE, 1992), 137-144, 152-166, 241-244; Samsó, ““Al-Bīrūn̄̄' in al-Andalus,” in From Baghdad to Barcelona: Studies in the Islamic Exact Sciences in Honour of Prof. Juan Vernet, ed. Josep Casulleras and Julio Samsó, 2 vols. (Barcelona: Instituto "Millás Vallicrosa” de Historia de la Ciencia Árabe, 1996), 2:583-612; Julio Samsó and Honorino Mielgo, "Ibn Isḥāq al-Tūnisī and Ibn Mu 'ādh al-Jayyānī on the Qibla,” in Julio Samsó, Islamic Astronomy and Medieval Spain (Aldershot: Variorum, 1994), ch. 6; Edward S.
} 
Latin translation made by Gerard of Cremona in the second half of the twelfth century, ${ }^{8}$ a fourteenth-century Hebrew rendering by Samuel ben Judah of Marseilles, and in a fourteenthcentury Latin-to-Italian translation. ${ }^{9}$ At least 25 manuscript copies of the Latin translation are still preserved, ranging chronologically from the thirteenth to the sixteenth century. ${ }^{10}$ These typically give the author's name as Abbomadhi or some variant thereof, which presumably

Kennedy, "Ibn Mu'ādh on the Astrological Houses," Zeitschrift für Geschichte der Arabisch-Islamischen Wissenschaften 9 (1994): 153-160; Jan P. Hogendijk, “Applied Mathematics in Eleventh Century Al-Andalus: Ibn Mu ādh al-Jayyānī and his Computation of Astrological Houses and Aspects," Centaurus 47 (2005): 87114; Emilia Calvo, "Ibn Mu ādh: Abū 'Abd Allāh Muḥammad ibn Mu'ādh al-Jayyān̄̄," in The Biographical Encyclopedia of Astronomers, ed. Thomas Hockey et al., 2 vols. (New York: Springer, 2007), 1:562-563; Josep Casulleras, La astrología de los matemáticos: la matemática aplicada a la astrología a través de la obra de Ibn Mu 'àdh de Jaén (Barcelona: Publicacions i Edicions de la Universitat de Barcelona, 2010); Casulleras, "The Astrological Computations Attributed to Ptolemy and Hermes in Medieval Arabic Sources," in Ptolemy's Science of the Stars in the Middle Ages, ed. David Juste, Benno van Dalen, Dag Nikolaus Hasse, and Charles Burnett (Turnhout: Brepols, 2020), 201-221, at pp. 213-217.

${ }^{8}$ Gerard of Cremona's translation was edited and translated into English by A. Mark Smith, "The Latin Version of Ibn Mu'ādh's Treatise 'On Twilight and the Rising of Clouds',” Arabic Sciences and Philosophy 2 (1992): 83-132. According to the Commemoratio librorum attached to Gerard's biography, he also translated Ibn Mu ādh's Tables of Jaén with their canons. See items no. 31 and 32 in Charles Burnett, "The Coherence of the Arabic-Latin Translation Program in Toledo in the Twelfth Century," Science in Context 14 (2001): 249-288, at p. 278. The canons survive in a sixteenth-century printed edition. See Heinrich Hermelink, "Tabulae Jahen," Archive for History of Exact Sciences 2, no. 2 (1963): 108-112. Excerpts are printed in Samsó and Mielgo, "Ibn Isḥāq al-Tūnisî” (n. 7), 23-25; Hogendijk, “Applied Mathematics” (n. 7), 106-109.

${ }^{9}$ A. Mark Smith and Bernard R. Goldstein, “The Medieval Hebrew and Italian Versions of Ibn Mu ādh's 'On Twilight and the Rising of Clouds," Nuncius 8 (1993): 611-643. The Hebrew version was translated into English and furnished with a commentary by Bernard R. Goldstein, "Ibn Mu 'ādh's Treatise On Twilight and the Height of the Atmosphere," Archive for History of Exact Sciences 17 (1977): 97-118.

${ }^{10}$ Smith, “The Latin Version” (n. 8), 90-91. 
originated as a contraction of $\mathrm{Abu}$ (or Ibn) and $\mathrm{Mu}$ ' $\overline{\mathrm{d}} \mathrm{dh} .{ }^{11}$ Giles was clearly familiar with this ascription, as his own text refers to the treatise under discussion as that qui dicitur Alb(er)omadhi de crepusculis matutino et vespertino. ${ }^{12}$

Its basic content may be summarized as follows: Ibn $\mathrm{Mu}$ 'ādh begins by arguing that morning and evening twilight share the same cause, which is that the Sun illuminates certain vapours that ascend from the Earth to the upper atmosphere. He arrives at this conclusion by the principle of exclusion, showing that ether and pure air are both too rarefied to be visible in this way. Another possibility he eliminates is that the light seen at twilight comes from distant parts of the Earth itself. According to Ibn $\mathrm{Mu}$ 'àdh, the human eye can see no further than 250 miles even from the summit of the highest mountains, which reach up to 8 miles. Yet 250 miles on Earth correspond to a celestial rotation of only $0 ; 15 \mathrm{~h}$, which is considerably less than the duration of twilight.

Ibn Mu'ādh next introduces four parameters that he will need to calculate the maximum height of the vapours above the horizon. These are: (i) the circumference of the Earth $(24,000$ miles $) ;{ }^{13}$ (ii) the mean distance of the Sun from the Earth $(1,110$ terrestrial radii); (iii) the ratio of the Sun's radius to the Earth's radius (5.5/1); (iv) the maximum depression of the Sun below the horizon at which twilight occurs $\left(19^{\circ}\right)$. Before he employs these parameters in the intended way, Ibn Mu'ādh offers three geometrical proofs that help set up his argument. They concern the following three theorems: (i) if two facing spherical bodies are equal in size and one is a source of light, it will illuminate exactly one-half of the

\footnotetext{
${ }^{11}$ A. I. Sabra, "The Authorship of the Liber de crepusculis, an Eleventh-Century Work on Atmospheric Refraction,” Isis 58 (1967): 77-85, at pp. 80-81; Smith, “The Latin Version” (n. 8), 84n3.

${ }^{12} B$, fol. 89ra.

${ }^{13}$ On the origin of this value, see Carlo Alfonso Nallino, Raccolta di scritti editi e inediti, vol. 5, ed. Maria Nallino (Rome: Istituto per l’Oriente, 1944), 293-294.
} 
other body; (ii) if the luminescent body is greater than the other, it will illuminate more than half; (iii) for both spherical bodies, it is true that any part that is not facing the other one cannot be seen from any point of this other body. Ibn $\mathrm{Mu}$ ' $\mathrm{a} d \mathrm{~h}$ then applies theorem (ii) to two bodies that have the relative sizes and mean distance of the Earth and Sun, finding that the Sun at any given time will illuminate $180 ; 27,52^{\circ}$ of the Earth's surface.

Before progressing to his principal argument, he uses another geometrical diagram to specify the conditions for twilight as well as to define the upper limit in altitude for any vapours illuminated during it. Having visualized the situation in this manner, he moves on to describe a diagram that enables him to compute this altitude by simple trigonometric means, using as input the illuminated arc of the Earth $\left(180 ; 27,52^{\circ}\right)$ and a solar depression angle of $19^{\circ}$. The stated result of approximately 52 miles $(c .88 \mathrm{~km})$ remained influential in Europe into the seventeenth century but was eventually abandoned in favour of much lower estimates once astronomers such as Kepler began to factor in atmospheric refraction. ${ }^{14}$

Summary of Giles of Lessines 's De crepusculis

Giles of Lessines's De crepusculis should not be mistaken for a commentary on Ibn Mu'ādh's work. Rather than explicating the underlying text paragraph by paragraph, or lemma by lemma, Giles's work is better described as a supplement written to furnish proofs and explanations of points that were not explicitly addressed in the original treatise. As Giles indicates in the prologue, his overall goal is to recapitulate the content of De crepusculis matutino et vespertino in a more rigorous fashion, by filling in certain blanks left by the

\footnotetext{
${ }^{14}$ For more on the historical background, see Bernard R. Goldstein, "Refraction, Twilight, and the Height of the Atmosphere,” Vistas in Astronomy 20 (1976): 105-107; A. Mark Smith, “Ptolemy, Alhacen, and Ibn Mu'adh and the Problem of Atmospheric Refraction," Centaurus 45 (2003): 100-115.
} 
original author. ${ }^{15}$ In accordance with this plan, Giles divided his text into three main parts, of which the first is an exercise in natural philosophy (physica), targeting the physical realities behind the phenomenon of twilight. Specifically, part I addresses six questions, each in a separate chapter:

1. Whether the Sun is the sole source of all light in the universe

2. Whether the stars receive their light from the Sun in the same way as the Moon

3. Why the stars can only be seen during night-time

4. Whether ether or air is visible in itself

5. Whether that which is illuminated during twilight is a part of the spheres of earth and water or some other body

6. Why Ibn Mu'ādh claims that the morning and evening twilight have the same shape and why they diverge in colour

Giles's responses in chapters (1) to (4) will be discussed in more detail below and can be summarized very briefly here. He argues that all celestial matter is luminous by nature and that the stars - even including the Moon — accordingly emit their own light, although their visibility increases when they also reflect light from the Sun. With regards to ether and air, Giles confirms that these are too rarefied to be illuminated by the Sun and hence cannot be

\footnotetext{
${ }^{15} \mathrm{~B}$, fol. 89ra: "Quia ergo intentio principalis in libro predicti auctoris est ostendere per viam demonstrationis quanta sit maior elevatio vaporum a superficie terre et aque [ms. aqua] et huius scientia dependet primo a cognitione nature et cause crepusculi utriusque, que physici est cognoscere, et secundo a scientia quatuor quantitatum [...] et horum scientia mathematice investigationis studio accipitur, in hiis autem que physici [ms. physica] sunt multa et obscura et dubia auctor breviter pertranseat et aliis que mathematicorum tamquam lucida aut alibi probata supponat, ideo circa has partes duas declarandas et circa tertiam principaliter, que intenditur, noster labor vertitur, quo utinam Deo placidus et hiis qui scientiam diligunt sit acceptus."
} 
seen. This means that the blue colour of the sky must be explained differently, as the result of an illusion created by the emission of visual rays from the eye.

In the fifth chapter, Giles furnishes a geometrical proof to the effect that whatever is illuminated during twilight will not be a part of the combined sphere of earth and water, taking in this a different, but complementary approach to Ibn Mu ādh. ${ }^{16}$ In the sixth and final chapter of part I, Giles introduces another diagram to explain Ibn Mu'ādh's statement that morning and evening twilight have the same appearance or figura. As Giles shows, one type of twilight is simply the reverse of the other, with either the Sun rising above the horizon or dipping below it. Why, then, is there an observable difference in colour? Giles reasons that this is due to differences in the quality of the illuminated vapours, which are caused by the Sun's diurnal motion. While the Sun is above the horizon, the vapours are heated and dried up and so appear redder in the evening. During the night, the vapours cool down and become more humid, so the next morning the Sun's rays give them a bluish hue. Since the Sun's action differs over the course of a year, variations in colour are also a seasonal phenomenon. Hence, morning twilight appears differently in winter than in other seasons. ${ }^{17}$

In part II, Giles moves on to discuss the four parameters that are required to perform Ibn Mu'ādh's calculation of the height of the atmosphere. Whereas Ibn Mu'ādh simply accepted these values on the authority of others, Giles provides an explanation of how each of them can be derived from empirical data and geometrical principles. He begins with a combination of philosophical and mathematical arguments to show that the Earth is spherical and located at the centre of the world. ${ }^{18}$ In the next step, he explains how the circumference of this sphere can be determined empirically in one of three different ways: (i) by measuring

\footnotetext{
${ }^{16} \mathrm{~B}$, fol. $92 \mathrm{rb}-\mathrm{vb}$.

${ }^{17} B$, fol. 93ra-va.

${ }^{18} \mathrm{~B}$, fols. 93vb-94vb.
} 
the elevation of the pole star; (ii) by measuring the meridian altitude of the Sun; (iii) by comparing the times of eclipses measured on different meridians. ${ }^{19}$ When it comes to the actual size of the circumference, Giles accepts the 24,000 miles already proposed in Ibn Mu'ādh's texts, which he attributes to the 'philosophers'. He also shows himself aware of an alternative estimate of 31,500 miles, which was obtained by converting Eratosthenes's famous value of 252,000 stades. ${ }^{20}$ For the second and third parameter (i.e., the mean distance between Earth and Sun and the ratio of their sizes) Giles heavily relies on the contents of the fifth book of Ptolemy's Almagest (5.11-16). ${ }^{21}$ He first explains how the lunar parallax can be established by measuring the Moon's angular distance from a star at different terrestrial latitudes and then gives a slightly simplified version of Ptolemy's proof in Almagest 5.13 to infer on this basis the Moon's greatest distance from the Earth. ${ }^{22}$ Helping himself to the eclipse-based method detailed in Almagest 5.15-16, Giles next uses the Moon's known distance to prove geometrically that the mean distance between the Earth and the Sun is 1,210 terrestrial radii and that the Sun's diameter is 5 1/2 times the Earth's diameter. ${ }^{23}$

In the final chapter of part II, Giles presents two different ways of determining the solar depression angle that corresponds to the onset of morning twilight or the end of evening twilight. His first option, which he describes in a somewhat elliptical fashion, is to find a fixed star whose position relative to the Sun is known and measure its altitude at the

\footnotetext{
${ }^{19} \mathrm{~B}$, fols. 94vb-95ra.

${ }^{20} B$, fol. 95ra. The value of 31,500 miles for the circumference appears in Pliny, Natural History 2.247.

${ }^{21}$ On these determinations, see Noel M. Swerdlow, Ptolemy's Theory of the Distances and Sizes of the Planets: A Study of the Scientific Foundations of Medieval Cosmology (Ph.D. diss., Yale University, 1968), 41-74; Albert Van Helden, Measuring the Universe: Cosmic Dimensions from Aristarchus to Halley (Chicago: University of Chicago Press, 1985), 15-20.

${ }^{22} B$, fols. 95 rb-96rb.

${ }^{23} \mathrm{~B}$, fols. $96 \mathrm{rb}-97 \mathrm{vb}$.
} 
beginning of twilight. The other option involves calculating the maximum depression angle of the Sun as a function of its declination and the local geographic latitude. Giles claims to know from experience that at a northern latitude of $48^{\circ}$ a clear night at the summer solstice is always dimly illuminated by the glimmer of twilight. Since a northern latitude of $48^{\circ}$ and a positive solar declination of $c .24^{\circ}$ (as is the case at the summer solstice) jointly imply a maximum depression angle of $c .18^{\circ}\left(90^{\circ}-48^{\circ}-24^{\circ}=18^{\circ}\right)$, this would be enough to confirm that the depression angle required for twilight is at least $18^{\circ} .^{24}$

Finally, part III of De crepusculis recapitulates the basic sequence of geometrical proofs contained in the original treatise, although Giles introduces certain modifications to achieve greater rigour and clarity. His most important change compared to Ibn Mu 'ādh is that he uses a mean distance Earth-Sun 1,120 terrestrial radii, as established in part II. ${ }^{25}$ Operating with this distance value, Giles deduces that the illuminated portion of the Earth corresponds to an $\operatorname{arc} 180 ; 22,25^{\circ}$, smaller than Ibn Mu 'ādh's $180 ; 27,52^{\circ} .{ }^{26}$ His final result, however, is tainted by computational and rounding error. Ibn $\mathrm{Mu}^{\prime} \mathrm{a} d \mathrm{dh}$ finds that the height of the atmosphere is $0 ; 48,50$ parts where the Earth's radius represents 60 parts. Since $24,000 / 2 \pi=$ $3818 ; 10,55$ miles, this amounts to saying that the height of the atmosphere is $51 ; 47,34$ miles

\footnotetext{
${ }^{24} B$, fol. 98ra: "Sed expertum est quod in illo tempore, sole scilicet existente in principio Cancri, in regione latitudinis 48 graduum semper in nocte serena apparere aliquid de splendore die, qui vocatur crepusculum, quare sole depresso sub orizonte per 18 gradus apparet crepusculum."

${ }^{25}$ Another author who revised Ibn Mu'ādh's calculation by employing the Ptolemaic value for the Earth-Sun distance is al- 'Urḍī (d. 1266). See George Saliba, "The Height of the Atmosphere According to Mu'ayyad alDīn al- 'Urḍ̄i, Quṭb al-Dīn Al-Shirāzī, and Ibn Mu 'ādh," in From Deferent to Equant: A Volume of Studies in the History of Science in the Ancient and Medieval Near East in Honor of E. S. Kennedy, ed. David A. King and George A. Saliba (New York: New York Academy of Sciences, 1987), 445-465, at p. 464; Smith and Goldstein, “The Medieval Hebrew and Italian Versions" (n. 9), 613.

${ }^{26} B$, fols. $99 \mathrm{vb}-100 \mathrm{ra}$.
} 
$+6 / 11$ of $1 / 3600^{\text {th }}$ of a mile. ${ }^{27}$ Giles simplifies the computation of the Earth's by rounding to 3800 miles, but then ends up dividing this number by 48, assuming that the height of the atmosphere is $1 / 48^{\text {th }}$ of the Earth's radius, when it should have been approximately $1 / 75^{\text {th }}$ $(0 ; 48 \times 0 ; 1)$. He thus concludes that the height of the atmosphere is 79 miles $(3800 \div 48=$ $79 ; 10) .^{28}$

\section{Stellar luminosity and its causes}

The first three chapters of Giles of Lessines's De crepusculis are closely interconnected in that they are all inspired by the same remark near the beginning of Ibn Mu'ādh's work, where he alludes briefly to a divide between two groups of scholars as to whether the Sun is the sole source of light among the celestial bodies. ${ }^{29}$ While the notion that the Moon depends on the Sun for its visibility was a matter of consensus, not everybody agreed with Ibn Mu'ādh that the same applied to all wandering and fixed stars. In the Islamic context, an important voice to the contrary was that of Ibn al-Haytham (d. 1039), who had penned a brief discourse arguing that the fixed stars and planets (other than the Moon) showed no visible phases or changes in their apparent size according to their elongation from the Sun, which revealed that they were all auto-luminous. ${ }^{30}$

Although Ibn al-Haytham's text was never translated into Latin during the Middle Ages, Giles of Lessines defended a rather similar set of ideas, thereby modifying one of the

\footnotetext{
${ }^{27}$ For the details of this calculation, see Goldstein, "Ibn Mu'ādh’s Treatise” (n. 9), 115-116; Smith, "The Latin Version" (n. 8), 131-132n25.

${ }^{28} B$, fol. $100 \mathrm{vb}$.

${ }^{29}$ Ibn Mu'ādh, De crepusculis, ed. Smith, “The Latin Version” (n. 8), 97, 11. 25-30.

${ }^{30}$ W. 'Arafat and H. J. J. Winter, "The Light of the Stars-A Short Discourse by Ibn al-Haytham," British Journal for the History of Science 5 (1971): 282-288.
} 
starting assumptions in Ibn Mu'ādh's Liber de crepusculis. The view he ended up opposing had been a well-established one in the medieval Latin tradition since the days of Isidore of Seville. ${ }^{31}$ In the thirteenth century, it was upheld by Albertus Magnus, whom Giles is likely to have known personally. ${ }^{32}$ Rather than citing his fellow Dominican, Giles located the opinion that the Sun is the sole source of light in the heavens in two twelfth-century Arabicto-Latin translations: the pseudo-Aristotelian De causis proprietatum et elementorum and the Liber de orbe attributed to Māshā'allāh. Their stance appeared to receive support from a

\footnotetext{
${ }^{31}$ See Isidore of Seville, Etymologiae 3.60, ed. and trans. Giovanni Gasparotto and Jean-Yves Guillaumin (Paris: Les Belles Lettres, 2009), 122-123; Isidore of Seville, De natura rerum 24.1, ed. Jacques Fontaine, Isidore de Seville: Traité de la nature (Bordeaux: Féret et fils, 1960), 261; Bede, De natura rerum 11, ed.
} Charles W. Jones, CCSL 123A (Turnhout: Brepols, 1975), 201. For scholastic views on this matter, see Roger Ariew, “The Phases of Venus before 1610," Studies in the History and Philosophy of Science 18 (1987): 81-92, at pp. 83-85; Edward Grant, Planets, Stars, and Orbs: The Medieval Cosmos, 1200-1687 (Cambridge: Cambridge University Press, 1994), 393-402.

${ }^{32}$ Albertus Magnus, De caelo et mundo, lib. 2, tr. 3, c. 6, ed. Paul Hossfeld, Alberti Magni Opera Omnia 5.1 (Münster: Aschendorff, 1971), 153-154; Albertus Magnus, Metaphysica, lib. 11, tr. 2, c. 26, ed. Bernhard Geyer, Alberti Magni Opera Omnia 16.2 (Münster: Aschendorff, 1964), 516, 11. 57-63. Albertus's commentary on De caelo underlies Peter of Auvergne, Quaestiones supra librum De caelo et mundo, lib. 2, q. 37, ed. Griet Galle (Leuven: Leuven University Press, 2003), 272-273, and is followed verbatim in Anonymi quaestiones supra librum de caelo et mundo, lib. 2, q. 18, ibid., 489-492. For antecedents, see Aristotle, De caelo II.11 (291b17); Averroes, Commentum magnum super libro De celo et mundo Aristotelis, trans. Michael Scot, lib. II, comm. 49, ed. Francis J. Carmody†, Rüdiger Arnzen, and Gerhard Endress, 2 vols. (Leuven: Peeters, 2003), 2:368. Concerning the likelihood of some personal connection between Giles of Lessines and Albertus Magnus, see C. Philipp E. Nothaft, “Origen, Climate Change, and the Erosion of Mountains in Giles of Lessines’s Discussion of the Eternity of the World (c.1260)," The Mediaeval Journal 4 (2014): 43-69, at pp. 43-45, 47, 50-51. 
biblical passage, Ecclesiasticus 42:16, and from certain statements on divine light contained in the pseudo-Dionysian corpus. ${ }^{33}$

In the case of the Moon, its status as a light-receiver was clearly demonstrable based on the occurrence of lunar eclipses. Since other celestial bodies shone at night with what seemed to be the same sort of light, one could reason by analogy that their illumination had to share a single cause with the Moon, namely, the Sun. ${ }^{34}$ Likewise, if the same light was brighter in some celestial bodies than in others, one could argue that there had to be one body in which this light reached its ultimate potential and perfect state, which was the Sun. Yet to be in this perfect state necessarily entailed being the cause of all the less perfect instantiations of the same effect. ${ }^{35}$ In the remainder of the first chapter, Giles extended this doctrine to the apparent auto-luminosity of things in the sub-lunar realm such fire and glow-worms (noctiluca), which shone most visibly when they were not within the light-cone of the Sun. His solution was to say that the power of the Sun impressed in such entities a disposition to

\footnotetext{
${ }^{33}$ See $B$, fol. $89 \mathrm{rb}-$ va, with references to Dionysius the Areopagite, De caelesti hierarchia, trans. John Scot Eriugena, c. 13, ed. Philippe Chevalier, Dionysiaca, 2 vols. (Bruges: Désclée de Brouwer, 1937), 2:946-949; pseudo-Dionysius Areopagita, De divinis nominibus, trans. John Sarrazin, c. 4, ed. Chevalier, 1:146-147; pseudo-Aristotle, De causis proprietatum et elementorum, c. 10, ed. and trans. Stanley Luis Vodraska (Ph.D. diss., University of London, 1969), 158; pseudo-Māshā'allāh, Liber de orbe (short version), c. 9, 12, ed. Joachim Heller, De elementis et orbibus coelestibus etc. (Nuremberg: Montanus \& Neuberus, 1549), sigs. D3vE3v, F2v-3v.

${ }^{34} B$, fol. 89va: "Sed que sunt eiusdem rationis necesse est habere eandem causam et principium eiusdem rationis, quia si esset alterius rationis causa unius quam alterius, cum causa per se assimileret sibi effectum in specie aut in ratione saltem, iam necessario essent effectus alterius et alterius rationis." This argument resembles Albertus Magnus, De caelo et mundo, lib. 2, tr. 3, c. 6, ed. Hossfeld (n. 32), 153, 1l. 82-93.

${ }^{35} \mathrm{~B}$, fol. 89va: "Sed perfectum est generare et producere tale quale ipsum est et habere causalitatem super omnia sui generis imperfecta; quare lux solis erit causa et origo omnis lucis corporum aliorum lucentium.”
} 
emit light under certain circumstances. In the case of glow-worms, this disposition arose because when their matter was dried and purified by solar rays, leaving behind a colour with luminescent qualities. ${ }^{36}$

Although Giles showed himself persuaded by these and other arguments that the Sun is the ultimate source of all light in the elementary spheres, he rejected the notion that this is also true of the stars and planets in the spheres above. Instead, he went on to argue, in the second chapter of part I, that all these celestial bodies generate their own light, however faint. Giles here referred to no previous authors, but merely echoed Ibn Mu'ādh's remark that certain people disagreed with his position. ${ }^{37}$ To these unnamed opponents, he attributed the following argument partly based on Aristotle's Metheora (1.3): since the Moon is the lowest of the celestial bodies, it is less pure than planets above it. It is in fact so close to the sublunar spheres that it partakes in their elemental nature. This explains why it cannot emit light in the same way as other celestial bodies. Owing to the celestial part of its nature, however, the Moon is endowed with a transparent and mirror-like surface, which enables it to reflect

\footnotetext{
${ }^{36} \mathrm{~B}$, fols. 89vb-90ra. Giles's explanation is not especially similar to that of Albertus Magnus, who argued that everything that shines in the dark contains a subtle form of fire. Albertus Magnus, De anima, lib. 2, tr. 3, c. 12, ed. Clemens Stroick, Alberti Magni Opera Omnia 7.1 (Münster: Aschendorff, 1968), 117.

${ }^{37} B$, fol. 90ra-rb: "Et de hoc dicit auctor quod quidam dissentiunt et in luna concordant omnes quod lumen suum accipiat a sole per aspectum ipsius solis ad ipsam solum. [...] Dissentiunt autem plurimi in stellis aliis a luna, dicentes quod stellarum lumen in eis formale est et non per resplendentiam radiorum solis sicut et lumen lune. [...] Huic vero positioni quam plurimi dissentiunt, sicut auctor innuit, precipue in stellis aliis a luna." Latin authors before Giles who had held this dissenting view include Macrobius, Commentariorum in Somnium Scipionis libri duo 1.19.8-10, 20.3, ed. and trans. Luigi Scarpa (Padua: Liviana Editrice, 1981), 208-209, 216217; Sisebut, Carmen de luna, 11. 45-52, ed. and trans. Fontaine (n. 31), 332-335; Hermann of Carinthia, De essentiis, bk. 1, 65vG-66vB, ed. and trans. Charles Burnett (Leiden: Brill, 1982), 132-137; Roger of Hereford, Computus I.10, ed. Alfred Lohr, CCCM 272 (Turnhout: Brepols, 2015), 160, 11. 13-15.
} 
light from the Sun. ${ }^{38}$ In putting things this way, Giles diverged markedly from Averroes, Albertus Magnus, Roger Bacon, and later scholastic writers, who argued that the appearance of the illuminated parts of the Moon did not conform to the laws of reflection and that it therefore had to borrow its light from the Sun in some other way. ${ }^{39}$

While the Moon exhibited visible phases, in accordance with the part of its surface illuminated by the Sun, other stars failed to do the same, which could be used as an argument in favour of their auto-luminosity. ${ }^{40}$ The author of pseudo-Māshā'allāh's Liber de orbe had tried to pre-empt this argument by insisting that these other stars were too distant from the observer to appear as anything more than small points. As evidence that the three superior planets shone by reflected sunlight, he cited the alleged fact that they appeared largest when

\footnotetext{
${ }^{38} \mathrm{~B}$, fol. 90rb-va. Giles saw in Isaiah 60:19 a possible scriptural confirmation of this view. The Moon is likened to a mirror in pseudo-Aristotle, De causis proprietatum et elementorum, c. 10, ed. and trans. Vodraska (n. 33), 159.
}

${ }^{39}$ Averroes, Commentum magnum super libro De celo et mundo Aristotelis, trans. Michael Scot, lib. II, comm. 49, ed. Carmody†, Arnzen, and Endress (n. 32), 2:367-368; Albertus Magnus, De caelo et mundo, lib. 2, tr. 3, c. 6, ed. Hossfeld (n. 32), 153-154; Roger Bacon, Opus Majus, pt. 4, dist. 4, c. 1, ed. John Henry Bridges, 3 vols. (Oxford: Clarendon Press, 1897-1900), 1:129; Roger Bacon, Opus tertium, c. 37, ed. and trans. Nikolaus Egel (Hamburg: Meiner, 2020), 244-245; Roger Bacon, De multiplicatione specierum, pt. 1, c. 5, 11. 29-38, ed. and trans. David C. Lindberg, Roger Bacon's Philosophy of Nature (Oxford: Clarendon Press, 1983), 70-73; Jean Buridan, Expositio et quaestiones in Aristotelis De caelo, bk. 2, qu. 19, ed. Benoît Patar (Louvain-la-Neuve: Éditions de l'Institut Supérieur de Philosophie, 1996), 485-486; Albert of Saxony, Quaestiones in Aristotelis De caelo, bk. 2, qu. 22, ed. Benoît Patar (Louvain-la-Neuve: Éditions de l’Institut Supérieur de Philosophie, 2008), 397-399; Nicole Oresme, Le Livre du ciel et du monde, bk. 2, ch. 16, ed. and trans. Alexander Menut and Alexander J. Denomy (Madison: University of Wisconsin Press, 1968), 456-459.

${ }^{40}$ See on the background Bernard R. Goldstein, "The Pre-Telescopic Treatment of the Phases and Apparent Size of Venus," Journal for the History of Astronomy 27 (1996): 1-12. 
in opposition to the Sun. ${ }^{41}$ Giles offered a different explanation of this phenomenon, noting that the superior planets were at perigee and hence closest to the observer when in opposition to the Sun — a point actually admitted by pseudo-Māshā'allāh. ${ }^{42}$ Even apart from this bit of astronomical theory, careful observation showed that the variations in brightness and apparent size were not strictly correlated with a planet's elongation from the Sun. Giles gave the example of the Moon, which, depending on its position relative to the ecliptic and the rays of the Sun, could sometimes appear larger at an elongation of $18^{\circ}$ than it did at $28^{\circ} .{ }^{43}$ As for the fixed stars, their auto-luminosity was indicated by the fact that their size did not vary visibly according to their angle with the Sun. ${ }^{44}$

To explain this state of affairs, Giles drew a sharp distinction between the corruptible matter of bodies in the sub-lunar realm and the incorruptible celestial spheres. According to him, all celestial matter possessed luminosity as an essential quality. The difference between celestial bodies that were visible and those that remained invisible to the eye, such as the orbs

\footnotetext{
${ }^{41}$ See $B$, fol. 90rb, referencing pseudo-Māshā’allāh, Liber de orbe (short version), c. 12, ed. Heller (n. 33), sigs. F2v-3v. This explanation is accepted by Witelo, Perspectiva IV, prop. 77, ed. Friedrich Risner, Opticae thesaurus (Basel: Episcopius, 1572), 152. The only planet where an increase is perceptible by the naked eye is Mars. See Christián Carlos Carman, “The Planetary Increase of Brightness during Retrograde Motion: An explanandum Constructed ad explanantem," Studies in History and Philosophy of Science 54 (2015): 90-101.

${ }^{42} B$, fol. 90va: "Est et alia ratio nota apud astronomos, quare stelle soli opposite, maxime planete superiores, sive etiam inferiores, quando sunt a sole indistantes, ut frequenter, maiores apparent propter ipsorum approximationem ad centrum terre, sicut quando sunt in propinquiori longitudine ad nos suorum deferentium sive suorum epiciclorum. Quia quanto res que videtur a remotis videtur, tanto minor apparet, et econtrario.” This issue is discussed in more detail in Roger Bacon, Opus tertium, c. 103, ed. and trans. Egel (n. 39), 844-847; Roger Bacon, De caelestibus, pt. 5.16, ed. Robert Steele, Opera hactenus inedita Rogeri Baconi, vol. 4, Liber secundus communium naturalium fratris Rogeri (Oxford: Clarendon Press, 1913), 442-443.

${ }^{43} B$, fol. 90va.

${ }^{44} B$, fol. 90 va-vb.
} 
carrying the planets, was that objects of the latter category lacked defined boundaries. ${ }^{45} \mathrm{~A}$ great advantage of this position was that it helped make sense of the first chapter of Genesis, which placed the creation of light and the heavens three days ahead of the creation of the Sun and other celestial bodies. On Giles's reading, the separation of light from darkness was simply the separation of luminous celestial matter from dark terrestrial matter. Light hence existed already on the first day of creation, although those parts of the heavens that were visible to the human eye, namely, the stars and luminaries, were only added on the fourth day, in order to serve "for signs, and for seasons, and for days, and years" (Genesis 1:14 $[\mathrm{KJV}]) .{ }^{46}$

This theory naturally entailed that even the Moon emitted some form of light, which Giles thought was borne out by its residual red glow during an eclipse. ${ }^{47}$ While this glow was produced by the Moon itself, it was also true that the Moon was so far removed from the purity of celestial matter that its brightness was much reduced compared to the other planets. Owing to this same lack of purity, some parts of the Moon's surface were less capable of receiving or reflecting sunlight than others, explaining the spots on its surface. ${ }^{48}$ Other

\footnotetext{
${ }^{45} \mathrm{~B}$, fol. 90vb: "Propter quod dico totam illam materiam essentaliter esse lucidam, sed non totam lucere nobis, id est apparere visibus nostris, eo quod visibus apparet corpus terminatum quod figuram piramidalem faciat." This is close to the 'vulgar' opinion Roger Bacon inveighs against in Opus maius, pt. 4, dist. 4, c. 1, ed. Bridges (n. 39), 128-129.

${ }^{46} B$, fol. 91 ra.

${ }^{47}$ The red glow is explained differently, as the product of accidental solar rays, in Roger Bacon, Opus maius, pt. $5=$ Perspectiva, pt. 2, dist. 3, c. 2, ed. and trans. David C. Lindberg, Roger Bacon and the Origins of Perspectiva in the Middle Ages (Oxford: Clarendon Press, 1996), 204-205.

${ }^{48} \mathrm{~B}$, fols. 90vb-91ra: "Unde etiam in eclipsibus lunaribus lune corpus frequenter videtur aliquando rusam, aliquando griseo et nigro colore permixtam, quando iam nullum radium solis recipit. Sed tunc non splendet eius lumen propter eius debilitatem et paucitatem, ex eo quod materia eius magis recedit a puritate prime materie.
} 
planets and the fixed stars were endowed with greater luminosity, although their brightness was not complete without the contribution of the Sun. ${ }^{49}$ By pointing out that the planets actually shone with a twofold light, of which one was derived from the Sun, Giles approached a middle ground that was also held by his younger contemporary Richard of Middleton (d. c.1308), who granted that planets and stars possessed a 'weak and tenuous' light of their own, to which the Sun added a second type of light. ${ }^{50}$

Propter quod et in superficie obiecta nobis propter convenientiam cum inferiori materia umbrose lumen recipit et maculam dicitur habere." On scholastic explanations of lunar spots, see Pierre Duhem, Le système du monde: histoire des doctrines cosmologiques de Platon à Copernic, vol. 9 (Paris: Hermann, 1958), 409-430; Grant, Planets (n. 32), 459-463; Peter of Auvergne, Quaestiones supra librum De caelo et mundo, ed. Galle (n. 32), $238 *-240 *$

${ }^{49} B$, fol. 91ra: "Stelle vero, quia superiories sunt primo participantes nobilitatem materie prime, magis habent de actuali lumine, sed tamen, ut credunt multi, tam luna quam stelle lumina perficiuntur in actu lucendi per solis aspectum et radios ipsius refractos ab ipsis ad nos." This conclusion resembles what is written about the stars in Bartholomaeus Anglicus, De proprietatibus rerum, bk. VIII, ch. 33 (Strasbourg: Husner, 1505), sigs. n1v-n2r. ${ }^{50}$ Richard of Middleton, II Sent., d. 13, a. 1, q. 4, in Super quatuor libros Sententiarum Petri Lombardi Quaestiones subtilissimae, 4 vols. (Brescia: de consensu superiorum, 1591), 2:159b: “Ad secundum dicendum quod in luna, \& in qualibet alia stella a sole, duplex est lux: una sibi naturalis, quae debilis est, \& tenuis: alia non sibi naturalis, quam a sole recipit. Prima non est eiusdem speciei cum luce solis. Secunda tamen ad eandem speciem reducitur cum luce solis. Est enim quaedam influentia eius non equivoce ab ea causata, nec tamen plene univoce. Unde luna per illam lucem per se non infrigidat, \& humectat, sed per virtutem suae forme substantialis, \& sue naturalis qualitatis, quae virtus ab ea immittitur cum radiis luminosis: luci enim per se non convenit, nisi lucere \& reducere colores in actum, ut possint visum movere." See also Albert of Saxony, Quaestiones in Aristotelis De caelo, bk. 2, qu. 22, ed. Patar (n. 39), 402: “Ad primam bene conceditur quod luna et quodlibet aliud astrum habet lumen debile et remissum ex se; sed quo habet lumen notabile quod nos notabiliter illuminat, hoc est a sole." A stronger case for the stars (other than the Moon) being self-luminous is made in Henry Bate, Speculum divinorum et quorundam naturalium 21.14, ed. Carlos Steel and Guy Guldentops (Leuven: Leuven University Press, 1996), 253-255. 
The third chapter of part I developed this position a bit further, by explaining why the planets and stars were hardly ever seen during daylight, despite possessing their own light. One underlying axiom of Giles's answer was that everything that became visible only did so through the action of light. ${ }^{51}$ Another was that any entity that moved from potentiality to actuality through the action of some strong outside force no longer had the potential of being actualized by a weaker force. Yet during the day, the act of seeing in the human eye was actualized by the light of the Sun, which was much stronger than the light of other celestial bodies. The latter accordingly were too weak to be seen through their own light during daytime. ${ }^{52}$ Occasionally, however, some celestial bodies could overcome this hurdle on account of their size or their close proximity to the Earth. Other than for the obvious case of the Moon, this was also true for Jupiter and especially for Venus, whose visibility became heightened when it was perigee and at a northerly latitude relative to the Sun, which prevented it from being submerged by its rays. ${ }^{53}$

\footnotetext{
${ }^{51}$ A possible source for this axiom is Averroes, Commentarium magnum in Aristotelis de anima libros, II, comm. 67, ed. F. Stuart Crawford (Cambridge, MA: Mediaeval Academy of America, 1953), 233-234, although Giles refers to "the Philosopher." B, fol. 91rb: "Prima propositio declaratur experientia et auctoritate, quia color est obiectum visus, non tamen potest videri actu nisi per actum lucidi, eo quod lux facit coloratum visibile in actu secundum Philosophum.”

${ }^{52} B$, fol. 91rb: "Sed de die oculus noster reducitur de potentia ad actum videndi per lumen solis illuminantem aerem et omnia corpora inferiora. Quare, cum sit eius actio fortior quam sit actio lucis alicuius stelle, necessario sequitur ex tertia propositione quod de die stelle non possunt videri. Quod enim videtur facit oculum de potentia vidente actu videntem."

${ }^{53} B$, fols. 91 rb-va.
} 


\section{The colour of the sky}

In the fourth chapter of part I, Giles approached an assumption crucial to Ibn Mu 'âdh's argument, namely, that neither celestial ether nor the air surrounding the spheres of earth and water could be perceived by the sense of vision. He set out to bolster this claim philosophically, by confronting certain objections founded on the apparent visibility of ether and air.

Consider this: does it not appear in clear weather that ether has an indigo colour? Moreover, how is it that we see the air illuminated, as happens during the day, if we cannot see the air itself? For light itself is not the thing that is seen, but an illuminated body is. If [we say] to this that the reason we do not see [the air] is that it is a medium through which we see other things, should it not also be the case that we do not see water or crystals, since they are a medium through which we see other things $?^{54}$

It seems useful to compare Giles's way of grappling with these problems with some of the relevant remarks in Roger Bacon's Perspectiva, also known as the fifth part of his Opus maius, which is the only thirteenth-century treatise on optics in which the colour of the sky receives serious attention. Another reason for looking at both writers in tandem is that Roger Bacon was familiar with Giles's Summa de temporibus and drew on it when composing the Opus maius in the second half of the 1260s, which indicates that they did not work in

\footnotetext{
${ }^{54} \mathrm{~B}$, fol. 91va: "Puta, nonne videtur ether in sereno quasi indicem habere colorem? Amplius et quomodo videmus aerem illuminatum, sicut apparet per diem, si ipsum aerem non videmus? Non enim lux in se videtur, sed corpus illuminatum. Ad hoc autem, etsi propter hoc ipsum non videmus, quia per medium ipsum alia videmus, numquid propter hoc aquam non videmus, aut cristallum, quia per medium ipsorum alia videmus?"
} 
isolation from each other. ${ }^{55}$ Owing to the complete lack of an identifiable date, it is unfortunately impossible to tell whether Giles's De crepusculis came after Bacon's Perspectiva or preceded it, in which case Bacon's own discussion of the colour of the sky may have partly been provoked by Giles's succinctly stated views on the matter.

What Giles shares with Bacon is his commitment to a theory of vision that involves an extramissionist element, insofar as it accepts that visual rays emanating from the eye are a necessary part of the seeing process. ${ }^{56}$ In accepting the existence of such rays, both authors were at odds with Avicenna and his Latin reader Albertus Magnus, who had launched a forceful critique of the extramission postulate in a treatise De sensu et sensato written before $1260 .{ }^{57}$ Unlike Albertus, Bacon argued that sight necessarily involved the eye sending out its species oculi or species visus towards the visible object, ${ }^{58}$ which incidentally provided him

\footnotetext{
${ }^{55}$ On Bacon's use of Giles of Lessines, see Ferdinand M. Delorme, "De auctore Compoti sub nomine Rogeri Baconis recenter editi," Antonianum 14 (1939): 313-322; C. Philipp E. Nothaft, "Climate, Astrology and the Age of the World in Thirteenth-Century Thought: Giles of Lessines and Roger Bacon on the Precession of the Solar Apogee," Journal of the Warburg and Courtauld Institutes 77 (2014): 35-60.

${ }^{56}$ On the continuing relevance of extramissionist ideas in thirteenth-century optical thought, see Lukáš Lička, "The Visual Process: Immediate or Successive? Approaches to the Extramission Postulate in $13^{\text {th }}$ Century Theories of Vision," in Medieval Perceptual Puzzles: Theories of Sense Perception in the $13^{\text {th }}$ and $14^{\text {th }}$ Centuries, ed. Elena Băltuţă (Leiden: Brill, 2020), 73-110. On the science of optics in the Middle Ages, chiefly in the thirteenth century, see David C. Lindberg and Katherine H. Tachau, "The Science of Light and Color, Seeing and Knowing," The Cambridge History of Science, vol. 2, Medieval Science, ed. David C. Lindberg and Michael H. Shank (Cambridge: Cambridge University Press, 2013), 485-511.

${ }^{57}$ Cemil Akdoğan, “Avicenna and Albert's Refutation of the Extramission Theory of Vision,” Islamic Studies 23 (1984): 151-157; Akdoğan, “Muslim Sources of Albert’s Contribution to Optics,” Islamic Studies 28 (1989): 211-216; Lička, “The Visual Process” (n. 56), 81-87.

${ }^{58}$ Roger Bacon, Opus maius, pt. 5 = Perspectiva, pt. 1, dist. 7, c. 2-4, ed. and trans. Lindberg (n. 47), 100-107. See Lička, "The Visual Process" (n. 56), 87-95.
} 
with an explanation as to why transparent media such as air and ether became visible if placed at sufficient distance. As Bacon put it, the species visus "is weakened with distance, so that although it will penetrate nearby air owing to its strength, it cannot penetrate the remote transparency of the heavens; consequently, the latter terminates vision." ${ }^{\circ 9}$ This process is aided by the fact that even a transparent substance can become opaque if "amassed over a great distance,"

as we observe in deep water, through which we cannot see the ground as we can see it through shallow water. For the prior parts of deep water cast their shadow on the posterior parts and a darkness that consumes the property of rarity is created, so that the entire body of water appears as though it were opaque. And it is the same with an extended [body of] air or the transparent heaven, on which account it is rendered visible - though it remains invisible when shallow. ${ }^{60}$

It is this accumulated opacity that accounts for the colour of the sky, as the more proximate parts of air cast their shadow on the more remote parts, producing a colour on the spectrum toward shadowy blackness. ${ }^{61}$

One crucial element in this account is the idea that vision is achieved only if something "terminates" it, that is to say, if the species coming from the eye is halted by an object with sufficient density. It is interesting to see that Giles embraced the same principle in De crepusculis, yet without accepting that ether or air could ever play the role of such an object. Instead of considering this possibility, he insisted that neither was capable of halting

\footnotetext{
${ }^{59}$ Roger Bacon, Opus maius, pt. 5 = Perspectiva, pt. 1, dist. 9, c. 1, 11. 25-28, trans. Lindberg (n. 47), 127.

${ }^{60}$ Roger Bacon, Opus maius, pt. 5 = Perspectiva, pt. 1, dist. 9, c. 1, 1l. 15-21, trans. Lindberg (n. 47), 125-127.

${ }^{61}$ Roger Bacon, Opus maius, pt. 5 = Perspectiva, pt. 1, dist. 9, c. 1, 11. 47-51, ed. and trans. Lindberg (n. 47), $126-129$.
} 
the propagation of light rays, which is what would have been required to render them visible in the first place. ${ }^{62}$ With this being so, his answer as to why the sky is blue was bound to differ significantly from Bacon's.

The fact, however, that ether appears to be indigo-coloured cannot really be due to the colour of ether, since [ether] is not a body with a determinate and fixed surface [and] has no colour. Instead, its appearance is in the eye. This is results from the fact that the eye looking outward sees through a medium of vapours, which are somewhat visible, because they possess a certain thickness, even if they are not wholly sufficient to terminate vision, such that other things could not be seen through them on account of their great transparency. [Thus, vision] is not halted at some defined visible thing, but, coming to nothing, it is reflected back against itself through the medium of these vapours, which, owing to their mirror-like nature, give back to the eye whatever colour they receive from it, while mixing it with the imperfect colour of these vapours. This is why the eye perceives a tawny colour below the indigo, as if this colour were contained in some thing that halts the vision directed at the highest ether, and it is not so. The way in which these vapours can somewhat thicken the air is also responsible for us saying that we can 'see' the day in the morning and in the evening. ${ }^{63}$

\footnotetext{
${ }^{62} B$, fol. 92ra: "Hiis visis patet quod nec aer, nec ether visibilia sunt per se, primo quia etiam si recipiunt lumen, tamen non lucent, nec resplendent aliquo dictorum modorum; secundo, quia non sunt corpora figurabilia figura terminabili et fixa propter sui raritatem et instabilitatem et ideo ad ipsa non potest radius lucis sistere, ut resplendeat; tertio, quia aer non potest distare ab oculo vidente nisi per interpositionem alterius corporis solidi et spissi ad quod iam radius visibilis terminaretur, et sic iam ipse aer ad oculum per actum lucis non posset deferri.

${ }^{63} \mathrm{~B}$, fol. 92ra-rb: "Quod autem videtur ether indici coloris non est secundum veritatem color etheris, quia non est corpus terminatum superifice fixa, non ullius coloris, sed huius apparentia sit in oculo, ex eo quod oculus videns extra se per medios vapores videt, qui quodammodo sunt visibiles, quia aliquo modo grossitiem habent,
} 
As understood by Giles of Lessines, ether was completely colourless for lacking density and a determinate surface, which rendered it incapable of halting either light rays or visual rays. In between the ether and the observer, however, were layers of atmospheric vapours that occupied a peculiar position between opaque and transparent, visible and invisible. Although their low density kept them from being clearly perceived, they possessed enough thickness to interfere with visual rays. Specifically, Giles attributed to these vapours the ability to act like a mirror and reflect any visual rays back toward the observer. In offering this explanation, he deviated very conspicuously from Roger Bacon, who in his Perspectiva taught that under normal circumstances the eye's visual rays were always strong enough to pass through any vapours contained in the air. He also expressly denied that vapours could act as mirrors for visual rays, citing the "remoteness of the reflecting surface and the lack of perfect smoothness, for vapours and clouds do not have altogether smooth and regular surfaces." ${ }^{64}$ Giles not only allowed for vapours to perform a mirror-like function, but he used this same process to account for the blue colour seen in the sky. According to Giles, this colour was a contribution made by the eye itself, although it remains unclear from his written remarks what part of the eye was supposed to be responsible. Did he perhaps believe that the colour

etsi non omnino sufficientem ad terminationem visus, quin per eos propter multam transparentiam alia possint videri ex eis, non terminatur in aliquam rem visibilem determinatam, sed sicut deficiens reflectitur eius visus in se ipsum per medios vapores, qui, cum sint speculares, reddunt ipsi oculo talem colorem qualem ab oculo recipiunt, mixtum tamen cum colore imperfecto ipsorum vaporum. Et hinc est quod apparet oculo color fulvus, quasi sub indicus [sic], quasi esset color in aliud qua terminaretur visus etheris suppremi et non est sic. Per istum etiam modum quo vapores aerem faciunt grossum aliqualiter dicimus nos videre diem in mane et in vespere."

${ }^{64}$ Roger Bacon, Opus maius, pt. 5 = Perspectiva, pt. 3, dist. 1, c. 5, 1l. 353-366, ed. and trans. Lindberg (n. 47), 282-283. 
seen in the sky was connected to the colour of one's iris? If so, would he have argued that one's perception of the sky was contingent on eye-colour? The text as we have it does not allow us to answer these questions. Even so, the notion that visual rays are carriers of colour, specifically blue, seems unique to Giles of Lessines and makes for one of the most original and puzzling features of De crepusculis. 